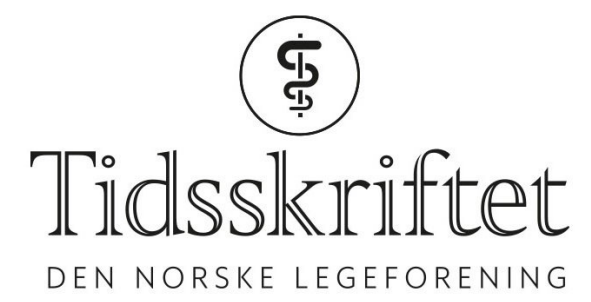

\title{
Antidiabetika ved type 2-diabetes - forvalter vi ny kunnskap riktig?
}

KRONIKK

\section{GARD FRODAHL TVEITEVÅG SVINGEN}

E-post: gard.frodahl.svingen@helse-bergen.no

Gard Frodahl Tveitevåg Svingen (f. 1978) er ph.d. og lege i spesialisering ved Hjerteavdelingen, Haukeland universitetssykehus.

Forfatter har fylt ut ICMJE-skjemaet og oppgir følgende interessekonflikter: Han har mottatt foredrags- og møtehonorar fra MSD Norge (produserer Janumet) og Sanofi-Aventis (produserer Amaryl). Han har ikke koblinger mot produsenter av nyere typer antidiabetika som er nevnt i teksten.

\section{KJETIL HALVORSEN LØLAND}

Kjetil Halvorsen Løland (f. 1986) er ph.d. og lege i spesialisering ved Hjerteavdelingen, Haukeland universitetssykehus

Forfatter har fylt ut ICMJE-skjemaet og oppgir følgende interessekonflikter: Han har mottatt foredrags- og møtehonorar fra Sanofi-Aventis (produserer Amaryl) og Novartis (produserer Eucreas). Han har ikke koblinger mot produsenter av nyere typer antidiabetika som er nevnt i teksten.

Den kliniske effekten av eldre antidiabetika på makrovaskulær sykdom og dødelighet har vært usikker. Nyere antidiabetika ser ut til å gi redusert risiko for slike endepunkter, og vi bør derfor vurdere å gi dem en mer fremtredende rolle i behandlingen av pasienter med type 2-diabetes.

Type 2-diabetes er en global epidemi (1) som øker risikoen for kardiovaskulær sykdom og tidlig død (2). Mikrovaskulær sykdom ved diabetes medfører typisk nefro-, nevro- og retinopati, men makrovaskulær sykdom, i hovedsak koronar hjertesykdom og cerebrovaskulær sykdom, er den viktigste årsaken til for tidlig død hos pasienter med type 2-diabetes (3).

I Norge, som i resten av verden, finnes en rekke antidiabetika på markedet, selv om det ifølge Reseptregisteret er sulfonylureapreparater som, etter metformin og insulin, i størst grad brukes (4). Bruken av sulfonylureapreparater er imidlertid omstridt, selv om effekten på langtidsblodsukker er godt dokumentert. Skepsisen kom allerede i 1971, da man i den randomiserte kliniske studien The University Group Diabetes Project (UGDP) rapporterte om økt kardiovaskulær død blant pasienter randomisert til tolbutamid (et førstegenerasjons sulfonylureapreparat) mot placebo (livsstilsendring)(5). Funnet skapte furore, men i etterkant tillot likevel legemiddelmyndighetene paradoksalt nok at nye antidiabetika kunne markedsføres uten først å ha blitt undersøkt i randomiserte kliniske studier for å belyse effekten på makrovaskulære endepunkter og død.

Siden publiseringen av resultatene fra UGDP-studien var det inntil nylig kun biguanidet metformin som hadde vist seg å redusere totaldødeligheten sammenlignet med annen 
antidiabetisk behandling $(6,7)$. The United Kingdom Prospective Diabetes Study (UKPDS) var en stor, randomisert klinisk studie med primærhensikt å teste intensiv og målrettet behandling mot konvensjonell senkning av langtidsblodsukker blant pasienter med nylig påvist type 2-diabetes (6). Primæranalysen viste ingen effekt verken på makrovaskulær sykdom eller død (6), men i en substudie (UKPDS-34) blant knapt 800 overvektige pasienter fant man $36 \%$ relativ risikoreduksjon i totaldød blant dem som fikk metformin sammenlignet med dem som fikk insulin og/eller sulfonylureapreparater (7). Til tross for at studien snart er 20 år gammel, at pasientene hadde lav bakgrunnsbehandling med f.eks. lipidmodifiserende medikamenter og at kombinasjonsbehandlingen av sulfonylurea og metformin noe paradoksalt ble forbundet med $ø k t$ risiko for diabetesrelatert $\mathrm{d} ø \mathrm{~d}$, er resultatene herfra hovedargument for dagens retningslinjer, der metformin angis som generelt førstevalg ved farmakologisk behandling av type 2-diabetes (8).

Hovedproblemet med manglende kunnskapsgrunnlag for antidiabetika har, med et visst unntak for metformin, vært at klinikere i flere tiår har måttet basere medikamentvalg på studier som har rapportert om antidiabetikas effekt på surrogatendepunkter, slik som langtidsblodsukker $\left(\mathrm{HbA}_{\mathrm{cc}}\right)$ (9). I tillegg bekreftet en metaanalyse fra Cochrane-samarbeidet i 2013 funnene fra The United Kingdom Prospective Diabetes Studys hovedstudie, nemlig at intensiv og målrettet blodsukkerbehandling ikke gir redusert risiko for makrovaskulær sykdom eller totaldødelighet, slik det gjør for mikrovaskulær sykdom (10). Forfatterne påpekte også den generelt dårlige kvaliteten på de randomiserte kliniske studiene som ble inkludert.

Sammenfattet har det altså hittil vært et svakt kunnskapsgrunnlag for gunstig klinisk effekt av intensiv blodsukkerbehandling og valg av spesifikke antidiabetika når det gjelder makrovaskulær sykdom og totaldødelighet. Behovet for adekvat designede studier med harde endepunkter har derfor vært stort, og etter publisering av saken om rosiglitazons assosiasjon med $\emptyset \mathrm{kt}$ risiko for hjerteinfarkt (11) satte endelig amerikanske legemiddelmyndigheter (U.S. Food and Drug Administration, FDA) krav om at ved nye typer antidiabetika som skulle lanseres etter 2008 måtte legemiddelselskapene demonstrere en akseptabel risikoprofil for kardiovaskulær sykdom for å få markedsføringstillatelse (12).

\section{En ny æra}

Den dobbeltblindede randomiserte studien EMPA-REG OUTCOME inkluderte over 7 ooo pasienter med type 2-diabetes og svært høy risiko for makrovaskulær sykdom (13). Halvparten ble randomisert til fortsatt konvensjonell antidiabetisk behandling (hovedsakelig metformin, insulin og sulfonylurea), mens den andre halvparten også fikk $10 \mathrm{mg}$ eller $25 \mathrm{mg}$ empagliflozin. Empagliflozin hemmer en glukosetransporten i nyrene og $\emptyset$ ker dermed utskillelsen av glukose. Resultatene ble publisert høsten 2015 og viste at gruppen som fikk empagliflozin, uavhengig av dose, etter en oppfølgingsperiode på drøye tre år fikk en relativ risikoreduksjon (RRR) i total (35\%) og kardiovaskulær (38\%) død samt sykehusinnleggelse for hjertesvikt (32\%). Gjennomsnittlig nedgang i langtidsblodsukker var o,2-0,4\%. Studien viste altså bedre overlevelse hos pasienter med svært høy risiko, men der blodsukkersenkningen i seg selv ikke så ut til å kunne forklare hele effekten. Følgelig godkjente amerikanske legemiddelmyndigheter (FDA) nylig empagliflozin for bruk til reduksjon av kardiovaskulær død hos type 2-diabetikere (14). En tilsvarende godkjenning er fremdeles ikke gitt av europeiske legemiddelmyndigheter.

I løpet av det siste året har store, dobbeltblindede randomiserte studier med de glukagonlignende peptid-1 (GLP-1)-analogene liraglutid og semaglutid vist til dels stor relativ risikoreduksjon for kardiovaskulære hendelser og/eller død i forhold til fortsatt konvensjonell behandling. I en av studiene ble det randomisert 9 ooo pasienter med type 2diabetes og høy kardiovaskulær risiko til enten 1,8 mg liraglutid subkutant hver andre uke eller placebo på toppen av konvensjonell behandling (hovedsakelig metformin og sulfonylurea). Etter tre år var reduksjonen i $\mathrm{HbA}_{\mathrm{tc}} \mathrm{O}, 4 \%$ større i intervensjonsgruppen enn i placebogruppen. Etter knapt fire års oppfølging var det $26 \%$ relativ risikoreduksjon for 
totaldød og 22\% for kardiovaskulær død i favør av liraglutid, og det var også en tendens mot lavere risiko for ikke-dødelig hjerteinfarkt og hjerneslag (14).

Semaglutid er en GLP-1-analog som foreløpig ikke tilbys kommersielt, men ble sammenlignet med standard behandling (overveiende biguanider, insulin og sulfonylurea) i en gruppe på over 3 ooo pasienter med type 2-diabetes og svært høy risiko for kardiovaskulær sykdom (15). Etter drøye to års oppfølging hadde pasienter i intervensjonsgruppen en doseavhengig o,7-1,0\% reduksjon i $\mathrm{HbA}_{\mathrm{tc}}$ i forhold til placebogruppen. Pasienter som fikk semaglutid hadde også en relativ risikoreduksjon på $26 \%$ for kardiovaskulær død eller ikke-dødelig hjerteinfarkt eller hjerneslag, hvorav redusert risiko for hjerneslag isolert sett også var statistisk signifikant. Det var ingen forskjell i totaldød mellom gruppene.

I de tre nyere studiene det her refereres til, har effekten på mikrovaskulær sykdom vært inkonsistent. En nyrebeskyttende effekt er rapportert for empagliflozin (13). Liraglutid ga også lavere risiko for nefropati (14), en effekt til felles med semaglutid, men som igjen ga økt forekomst av retinopati (15).

\section{Hvordan tolke de nyere studiene}

Tolkningen av studiene på nyere typer antidiabetika problematiseres av flere forhold. For det første er intervensjonsbehandlingen testet som tillegg til konvensjonell blodsukkersenkende behandling, dvs. ikke som monoterapi mot placebo. Den relative behandlingsgevinsten kan ha blitt påvirket av endringer i den konvensjonelle behandlingen i løpet av studien, for eksempel ved økt bruk av sulfonylureapreparater eller mer bruk av insulin hos pasientene i placebogruppen $(13,14,15)$. For det andre har de nyere studiene hatt såkalt ikke-underlegenhetsstudie-design. Det betyr at den primære alternative hypotesen har gått ut på at ny behandling ikke er uakseptabelt dårligere enn konvensjonell behandling (16). Imidlertid er ikke et slikt studiedesign til hinder for å rapportere overlegenhet for aktiv behandling, selv om dette blir å betrakte som et sekundærfunn (16). Et tredje poeng er at det ikke er klarlagt nøyaktig hvilke mekanismer som ligger bak effektene av nyere typer antidiabetika på kardiovaskulære endepunkter og/eller død. Dette illustreres også av en viss inkonsistens innad i medikamentklassene, f.eks. viste ikke GLP-1-analogen lixisenatid kardiovaskulær gevinst i forhold til konvensjonell behandling hos pasienter med akutt koronarsyndrom (17).

I våre øyne bør likevel fokus på virkningsmekanismer være av underordnet interesse, all den tid effekten på viktige, harde, kliniske endepunkter nå er dokumentert for empagliflozin, liraglutid og semaglutid. Videre må medikamentsikkerhet alltid vurderes. Erfaringen med de nyere antidiabetika er naturligvis begrenset, og det er reist spørsmål om sikkerheten ved bl.a. liraglutid med tanke på neoplasmer (15). Spørsmålet blir likevel om vi heller skal stole mer på sikkerheten ved bruk av andre, etablerte medikamenter, men der kunnskapsgrunnlaget i størst grad hviler på observasjonsdata.

\section{Oppdaterte retningslinjer for diabetesbehandling}

Nye norske retningslinjer for diabetesbehandling ble publisert av Helsedirektoratet $\mathrm{i}$ september 2016 (8). Behandlingsmålene for type 2-diabetes er primært rettet mot senkning av $\mathrm{HbA}_{\mathrm{cc}}$. I tråd med amerikanske og europeiske retningslinjer er metformin fremdeles førstevalg, mens det ikke foreligger rangering for valg av andrevalgspreparater, der bl.a. sulfonylurea, empagliflozin og liraglutid inngår som alternativer. Behandleren anmodes om å foreta en totalvurdering, der medikamentsikkerhet og erfaring vektlegges spesielt. I de siste europeiske retningslinjene for preventiv kardiologi blir også metformin anbefalt som førstelinjebehandling (IB-anbefaling) hos pasienter med type 2-diabetes, mens empagliflozin får en IIaB-anbefaling, dog med en kommentar om at SGLT2-hemmere bør vurderes tidlig i behandlingsforløpet hos pasienter med type 2-diabetes og etablert kardiovaskulær sykdom (18). 
Kunnskapsgrunnlaget er altså svakt for dagens praksis og anbefaling med perorale antidiabetika for harde makrovaskulære endepunkter og dødelighet, dog med et lite unntak for metformin. I gjeldende, norske retningslinjer fremheves det at den lange erfaringen med bl.a. metformin er en fordel (8), men bivirkninger og andre faresignaler blir ikke alltid fanget godt nok opp i observasjonsstudier, hvor i tillegg kontrollgruppene ofte mottar flere andre antidiabetika i kombinasjon. Etter vår mening er det uheldig å likestille nyere typer antidiabetika med alternativer som har udokumentert, og i verste fall skadelig, effekt på harde, kliniske endepunkter (12). Videre er de omtalte nyere studiene med på å utfordre sentreringen rundt $\mathrm{HbA}_{1 \mathrm{c}}$ som primærmål i antidiabetikabehandlingen.

Vi ønsker en debatt om bruk og prioritering av antidiabetiske midler for å redusere kardiovaskulær sykelighet og død blant pasienter med type 2-diabetes, og spesielt dem med høy til svært høy utgangsrisiko.

\section{LITTERATUR:}

1. Whiting DR, Guariguata L, Weil C et al. IDF diabetes atlas: global estimates of the prevalence of diabetes for 2011 and 2030. Diabetes Res Clin Pract 2011; 94:311 - 21. [PubMed][CrossRef]

2. Tancredi M, Rosengren A, Svensson AM et al. Excess Mortality among Persons with Type 2 Diabetes. N Engl J Med 2015; 373: 1720 - 32. [PubMed][CrossRef]

3. Huxley R, Barzi F, Woodward M. Excess risk of fatal coronary heart disease associated with diabetes in men and women: meta-analysis of 37 prospective cohort studies. BMJ 2006;332: $73-8$.

[PubMed][CrossRef]

4. Folkehelseinstituttet. Reseptregisteret. http://www.reseptregisteret.no/ (2.2.2017).

5. Meinert CL, Knatterud GL, Prout TE et al. A study of the effects of hypoglycemic agents on vascular complications in patients with adult-onset diabetes. II. Mortality results. Diabetes 1970; 19: 789 - 830. [PubMed]

6. UK Prospective Diabetes Study (UKPDS) Group. Intensive blood-glucose control with sulphonylureas or insulin compared with conventional treatment and risk of complications in patients with type 2 diabetes (UKPDS 33). Lancet 1998; 352: 837-53. [PubMed][CrossRef]

7. UK Prospective Diabetes Study (UKPDS) Group. Effect of intensive blood-glucose control with metformin on complications in overweight patients with type 2 diabetes (UKPDS 34). Lancet 1998; 352 : 854-65. [PubMed][CrossRef]

8. Helsedirektoratet. Nasjonal faglig retningslinje for diabetes. https://helsedirektoratet.no/retningslinjer/diabetes (18.3.2017).

9. Lipska KJ, Krumholz HM. Is Hemoglobin A1c the Right Outcome for Studies of Diabetes? JAMA 2017; 317: 1017 - 8. [PubMed][CrossRef]

10. Hemmingsen B, Lund SS, Gluud C et al. Targeting intensive glycaemic control versus targeting conventional glycaemic control for type 2 diabetes mellitus. Cochrane Database Syst Rev 2013; 11: CDoo8143. [PubMed]

11. Nissen SE, Wolski K. Effect of rosiglitazone on the risk of myocardial infarction and death from cardiovascular causes. N Engl J Med 2007; 356: 2457 - 71. [PubMed][CrossRef]

12. Food and Drug Administration. Guidance for industry: diabetes mellitus - evaluating cardiovascular risk in new antidiabetic therapies to treat type 2 diabetes. https://www.fda.gov/downloads/Drugs/.../Guidances/ucmo71627.pdf(5.3.2017).

13. Zinman B, Lachin JM, Inzucchi SE. Empagliflozin, Cardiovascular Outcomes, and Mortality in Type 2 Diabetes. N Engl J Med 2016;374: 1094. [PubMed]

14. LEADER Trial Investigators. Liraglutide and Cardiovascular Outcomes in Type 2 Diabetes. N Engl J Med 2016; 375: 311 - 22. [PubMed][CrossRef]

15. SUSTAIN-6 Investigators. Semaglutide and Cardiovascular Outcomes in Patients with Type 2 Diabetes. N Engl J Med 2016; 375: 1834 - 44. [PubMed][CrossRef] 
16. Schumi J, Wittes JT. Through the looking glass: understanding non-inferiority. Trials 2011; 12: 106. [PubMed][CrossRef]

17. ELIXA Investigators. Lixisenatide in Patients with Type 2 Diabetes and Acute Coronary Syndrome. $N$ Engl J Med 2015; 373: 2247-57. [PubMed][CrossRef]

18. Authors/Task Force Members. 2016 European Guidelines on cardiovascular disease prevention in clinical practice: The Sixth Joint Task Force of the European Society of Cardiology and Other Societies on Cardiovascular Disease Prevention in Clinical Practice (constituted by representatives of 10 societies and by invited experts)Developed with the special contribution of the European Association for Cardiovascular Prevention \& Rehabilitation (EACPR). Eur Heart J 2016; 37: 2315 - 81.

[PubMed][CrossRef]

Publisert: 21. august 2017. Tidsskr Nor Legeforen. DOI: 10.4045/tidsskr.17.0002

Mottatt 1.1.2017, første revisjon innsendt 19.3.2017, godkjent 14.5.2017.

(C) Tidsskrift for Den norske legeforening 2020. Lastet ned fra tidsskriftet.no 